\title{
Natural and anthropogenic agents in the present geomorphological dynamics of the Torrent Corlo mountain catchment (Northern Apennines, Italy)
}

\author{
Doriano CASTALDINI ${ }^{1}$, Paola CORATZA ${ }^{1}$, Giovanni TOSATTI ${ }^{1}$ \\ ${ }^{1}$ Department of Chemical and Geological Sciences, University of Modena and Reggio Emilia, Italy \\ Received 31 October 2017; Revised 20 November 2017; Accepted 1 December 2017 \\ *Correspondence to: Paola CORATZA, e-mail: paola.coratza@unimore.it
}

\begin{abstract}
The morphological changes affecting a small mountain catchment in the territory of Modena (Italy) have been taken into account. In particular, based on detailed field surveys and analysis of remote sensing imagery, an assessment was made on the natural and anthropogenic agents which have modelled this basin in the past 80 years. For several decades, the Torrent Corlo catchment was subject to intense exploitation of clay raw materials in order to supply a flourishing ceramic tile industry. As a result, a strong, negative impact has affected the landscape and, in some areas, the geomorphological evolution due to man's activities greatly surpasses the changes ascribable to natural processes, such as landslides or stream channel processes. Since 2008, all quarrying activities have ceased and the local public administration has started a project of reclamation of the abandoned clay pits, although it will not be possible to restore completely the original, natural features of this catchment. A comparison is made with the sub-catchment Rio delle Vigne valley, which has been spared from anthropogenic changes and has been affected only by natural gravity-induced processes, which have produced some twelve landslides. The final products of this research are the implementation of the first geomorphological map of the T. Corlo mountain catchment and an updated version of the hydrological hazard map, in which active and dormant landslides are much more numerous than those mapped in any other previous geological map (s.l.). These documents can be utilized for any intervention by public boards aiming at recuperating and improving this intensely exploited area.
\end{abstract}

KEYWORDS

Morphogenetic agents; gravitational processes; quarrying activities; geomorphological evolution; Northern Apennines; Italy 


\section{Introduction}

The rapid urban and industrial development, which has affected large portions of northern Italy since the mid-1950s, has also caused heavy impacts on the territory, sometimes increasing geological instability processes in areas already predisposed to these. This is the case of the study area, which is characterised by the presence of silty-clayey rock types, naturally subject to intense erosion and slope movements. At the same time, these raw materials are particularly suitable for the production of ceramic tiles. Therefore, they were heavily dug out from large clay pits for a long time, without considering the consequences on the landscape and the environment. This research was carried out in order to identify landforms created by past and present morphogenetic processes in the small Torrent Corlo mountain catchment (Northern Apennines, Italy) and to quarrying activities carried out for several decades in the same area. The data collected were finally represented in a detailed geomorphological map, with the purpose of providing a starting document for the public authorities in charge of defining and undertaking upgrading and stabilisation measures.

\section{Site description}

The mountain catchment of the T. Corlo is located in the western sector of the Modena Apennine foothills, in the Municipality of Fiorano Modenese, which is part of the industrial district of SassuoloFiorano-Maranello, where hundreds of factories were built, starting from the early 1950s, for the production of ceramic tiles (Fig. 1).

The T. Corlo is a small watercourse that runs across the Modena Apennine hills for about $3 \mathrm{~km}$; it reaches the Modena Plain at Fiorano and, some 3 $\mathrm{km}$ downstream, flows into the Fossa di Spezzano stream, which belongs to the River Secchia catchment.

The T. Corlo catchment has a sub-continental temperate climate with average precipitation of about $700-800 \mathrm{~mm} / \mathrm{year}$ and average temperature of $12-13{ }^{\circ} \mathrm{C}$ (Fazzini, 2007). The study area stretches over 175 ha with altitudes ranging between $125 \mathrm{~m}$ and $310 \mathrm{~m}$ approx.

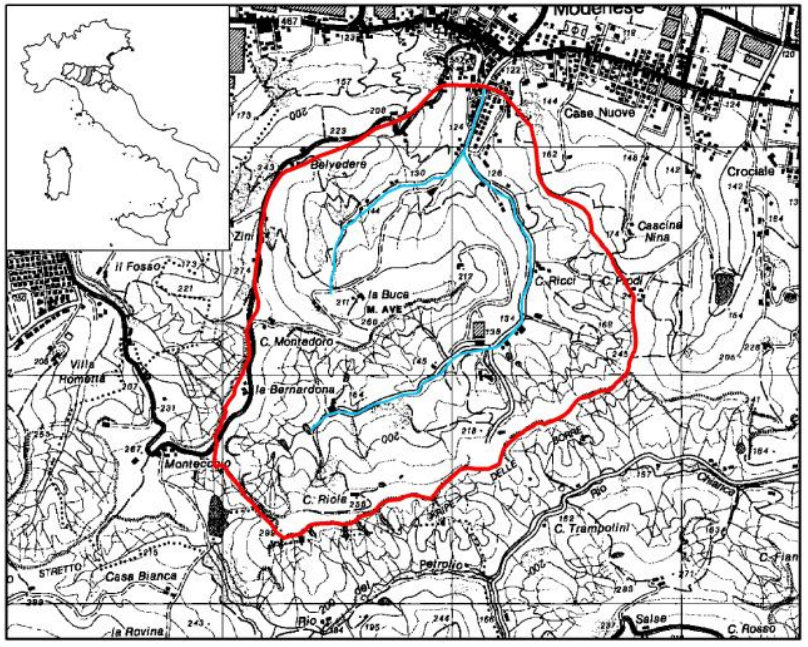

Figure 1 Geographic setting of the Torrent Corlo mountain catchment. Shaded area in inset is the Province of Modena.

\subsection{Geological and geomorphological setting}

From the geological viewpoint, the area is located in the Modena Apennine margin, where marine siltyclayey rock types of the Plio-Pleistocene "Argille Azzurre" Formation crop out (Gasperi et al., 2005). They are marly clays, grey and blueish-grey clayey and silty marls, cropping out in medium to thin layers, with joints hardly visible owing to bioturbation. Locally, discontinuous, thin, laminated layers of fine biocalcarenites and yellowish siltites are found (Gasperi et al., 2005; Regione EmiliaRomagna, 2017). In the study area there are sand intercalations exposed in medium-sized strata, particularly visible in the upper part of the left handside slope of the T. Corlo valley (Fig. 2). The general setting of the strata shows a NW-SE strike, with a $15^{\circ}$ to $40^{\circ} \mathrm{NE}$ dip (Fig. 3). On the right hand-side of the T. Corlo valley, these rock types are affected by a WSW-ENE trending fault. In the lowest part of the T. Corlo catchment, fine alluvial deposits are exposed, which belong to the Modena Unit sediments dating from the $6^{\text {th }}$ century CE. This Unit comprises gravel deposits turning to alluvial terrace sand and silt deposits (cf. Gasperi et al., 2005, Regione Emilia-Romagna, 2017). 


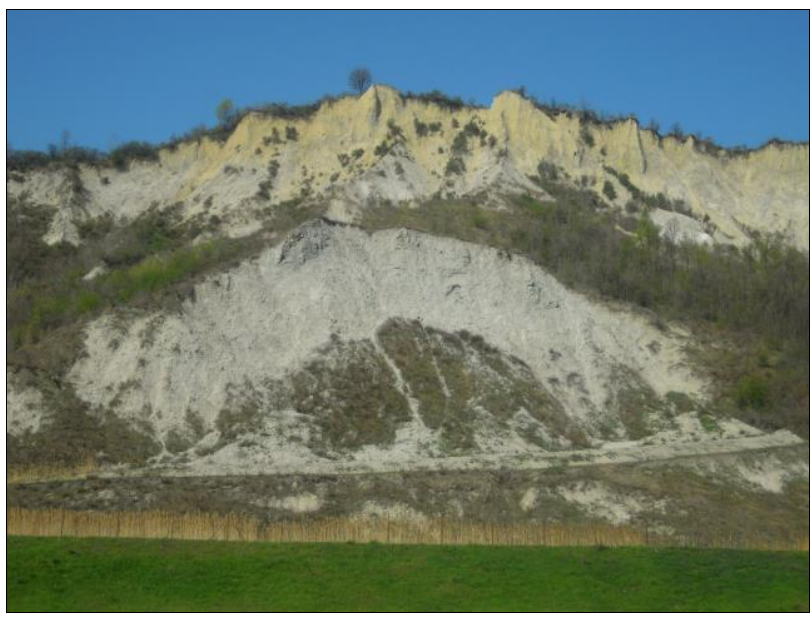

Figure 2 Argille Azzurre Formation (FAA) cropping out on the left-hand slope of the T. Corlo upper valley. In the top part of the cliff, ochre coloured sand layers are visible.

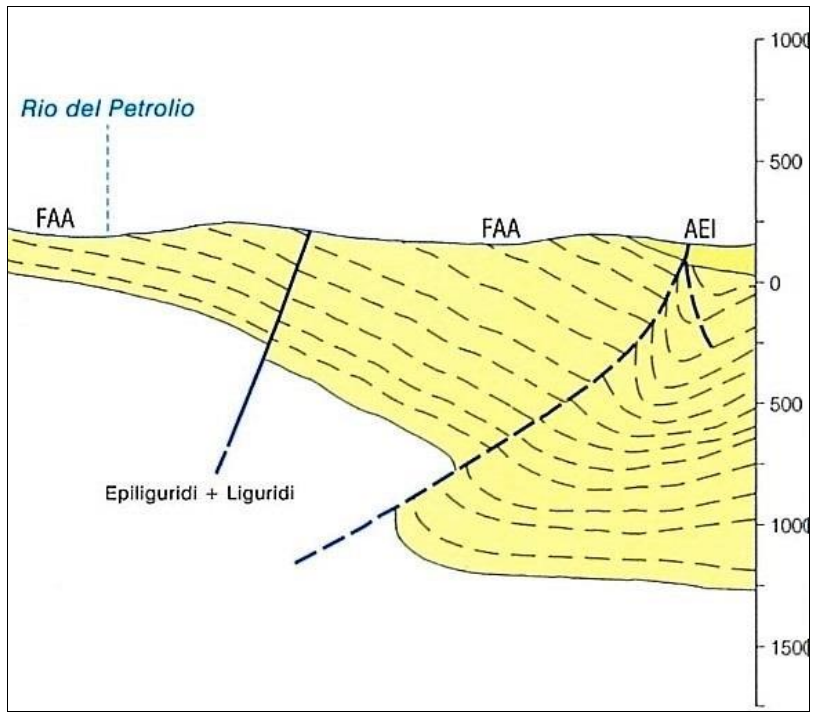

Figure 3 Geological section of the eastern sector of the study area. Legend. FAA: Argille Azzurre Formation (Lower Pliocene - Lower Pleistocene); AEI: Emilia-Romagna lower synthem of the Middle Pleistocene (after Gasperi et al., 2005). In stratigraphy a "synthem" is a chronostratigraphic unit that defines an unconformity-bounded regional body of sediments and represents a cycle of sedimentation in response to changes in relative sea level or tectonics.

The geomorphological features of the study area are controlled by the widespread presence of clay. The main landforms are related to gravitational, running-water erosional processes, and anthropogenic activities. The most evident natural morphological features to be observed on the slopes of this mountain catchment, as well as in the surrounding areas, are badland landforms locally named "calanchi". Indeed, badlands are one of the most spectacular erosion landforms of the Po Plain side of the Apennines. Typically, they are composed of silty-clayey rock types and are characterised by a very fine drainage network and short, steep slopes with narrow interfluves. Various small to averagesized earth slides and earth flows are found in the area. Surface deposits are mostly made up of very fine materials sedimented by the T. Corlo on the valley floor and by rill-wash at the foot of the slopes. The main anthropogenic landforms consist of abandoned clay pits on the slopes of the midsector of the valley, which produced the raw material for the ceramic tile industry.

\section{Materials and methods}

The research here presented was carried out according to the traditional methods used in geomorphology and included the following steps:

i) A retrospective study was carried out based on bibliographic sources, research on historical maps, reports from technicians of the Municipality of Fiorano Modenese and accounts of the local population, in order to gain data on the spatial and temporal distribution of historical slope movements and anthropogenic activities. This task provided information about: 1) types of landslides, 2) origin of landslides (conditioning and triggering factors), with special attention on the role played by human activity on the generation/reactivation of slope movements, 3) reactivation frequency of particular landslides, 4) excavation and termination phases of quarrying activities.

ii) A multi-temporal analysis of aerial photographs and satellite images was carried out, with special attention given to erosional and gravitational phenomena. To achieve this aim, traditional stereoscopic and digital photogrammetry techniques were utilized. The documents considered in this study are listed in Table 1. The available digital data were overlaid and compared using GIS software, also by means of 3D elaborations in order to better appreciate morphological features. The study of landforms, represented in a sequence of 
(Northern Apennines, Italy)

images corresponding to different years, allowed the evolution of the study area to be reconstructed.

iii) Field survey and related mapping was carried out at a 1:5,000 scale, with particular attention to the cartographic representation of instability phenomena and to the morphological features of the study area. The implementation of the geomorphological map followed the scheme and legend of Italian mapping methodology (Gruppo di lavoro per la cartografia geomorfologica, 1994) and was updated on the basis of recent geomorphological maps (e.g. Castaldini et al., 2009; Panizza et al., 2011; Bruschi et al., 2012). According to the legend of this map, landforms and associated deposits are depicted by using different coloured symbols, according to the geomorphological processes responsible for their development, whereas their state of activity is marked by means of colour shades (cf. Dramis and Bisci, 1998; Dramis et al., 2011; Panizza et al., 2011). This 1:5,000 scale geomorphological map, constructed using GIS technology, provides a useful comprehensive basis as well as an original document for the area and an organic framework of past and present morphogenesis.

Table 1 Cartographic documents examined. IGM: Italian Military Geographic Institute; GAI: Aerial Italian Group; CTR: Regional Technical Maps (CTR) of Emilia-Romagna Region; RER: Emilia-Romagna Region; GN: Geoportale Nazionale website; AGEA: Agenzia per le Erogazioni in Agricoltura; GE: Google Earth website; B/W: black \& white; C: colour.

\begin{tabular}{llll}
\hline Type of document & Date & $\begin{array}{l}\text { Scale / } \\
\text { Resolution }\end{array}$ & Note \\
\hline IGM map & 1935 & $1: 25,000$ & $\mathrm{~B} / \mathrm{W}$ \\
GAI aerial photos & 1954 & $1: 33,000$ & $\mathrm{~B} / \mathrm{W}$ \\
RER aerial photos & 1973 & $1: 15,000$ & $\mathrm{~B} / \mathrm{W}$ \\
CTR map & 1977 & $1: 10,000$ & $\mathrm{~B} / \mathrm{W}$ \\
Volo Italia: & 1988 & $1: 70,000$ & $\mathrm{~B} / \mathrm{W}$ \\
aerial photos & 1994 & $1: 2,000$ & \\
GN website & & & \\
Volo Italia & 2000 & $1: 1,000$ & $\mathrm{C}$ \\
GN ortho-photos & & & \\
CTR map & 2005 & $1: 10,000$ & $\mathrm{C}$ \\
Volo Italia & 2006 & $1: 1,000$ & $\mathrm{C}$ \\
GN ortho-photos & & & \\
AGEA ortho-photos & 2008 & $0.5 \mathrm{~m}$ & $\mathrm{C}$ \\
GN website & 2012 & $1: 1,000$ & $\mathrm{C}$ \\
GE website & 2014 & $0.5 \mathrm{~m}$ & $\mathrm{C}$ \\
& 2016 & & \\
\hline
\end{tabular}

iv) Starting from the data collected in previous research phases, an updated version of the Province-Coordinated Territorial Plan (or simply PTCP Hydrological Hazard Maps of Provincia di Modena, 2009) was produced. The PTCP Hydrological Hazard Maps are thematic synthesis maps classifying the unstable zones as active or dormant landslides or as potentially subject to landsliding. They also outline critical areas in relation to hydrological instability, to which guidelines, regulations and directives are applied (see Table 2).

As highlighted by Castaldini et al. (2012b), the geological instability processes identified in many areas of the Modena Apennines do not correspond in several cases to those mapped by the Hydrological Hazard Maps. The main differences concern the presence, location and/or state of activity of slope instability phenomena.

It is important to stress how the contents of the PTCP Hydrological Hazard Maps (Provincia di Modena, 2009) have direct and constraining effects on the territorial planning of local boards. A peculiar situation for the Modena Province is that the PTCP Hydrological Hazard Maps represent the only reference plan for municipal urban planning with respect to hydrological safety regulations.

Table 2 Legend of the PTCP Hydrological Hazard Map (modified after Provincia di Modena, 2009).

\begin{tabular}{|c|c|c|}
\hline ZONE & CATEGORY & ELEMENTS CONSIDERED \\
\hline 1 & $\begin{array}{l}\text { Areas affected by } \\
\text { active landslides }\end{array}$ & $\begin{array}{l}\text { Landslides which are currently active or that have been } \\
\text { reactivated in the last } 30 \text { years (rock falls are also } \\
\text { included). }\end{array}$ \\
\hline 2 & $\begin{array}{l}\text { Areas affected by } \\
\text { dormant landslides }\end{array}$ & $\begin{array}{l}\text { Landslides that have not shown signs of activity in the } \\
\text { last } 30 \text { years and that could be reactivated by their } \\
\text { original causes; among these, there are block slides, } \\
\text { lateral spreads and Deep-seated Gravitational Slope } \\
\text { Deformations. }\end{array}$ \\
\hline 3 & $\begin{array}{l}\text { Potentially unstable } \\
\text { areas }\end{array}$ & $\begin{array}{l}\text { Quaternary deposits affected by evident superficial } \\
\text { morphogenetic processes such as creep, solifluction } \\
\text { etc.; alluvial fans; areas affected by relevant processes } \\
\text { due to running water (erosion, floods etc.); naturally } \\
\text { stabilized or relict landslides. }\end{array}$ \\
\hline
\end{tabular}

In their territorial-planning phase, Municipalities can adopt all data contained in the PTCP Hydrological Hazard Maps without any change, but 
they can also improve and update them by means of detailed investigations.

\section{Geomorphological map}

The geomorphological map (Plate 1) shows the geological and structural elements, hydrography, anthropogenic landforms, fluvial and slope landforms due to running water and gravityinduced slope landforms.

An important aspect concerns the "concept of activity", which should be applied in defining the dynamics of geomorphic processes (and related landforms and deposits) in general, and slope instability phenomena, in particular.

It is of paramount importance in applied geomorphology to distinguish "active", "dormant" or "non-active" processes. As definitions of these terms vary, we must define precisely how they are used. Since a geomorphological map was the base document for updating the PTCP Hydrological Hazard Map (see chapter 5), running water and gravity-induced landforms and deposits have been distinguished as "active" and "dormant", according to the definition given by Provincia di Modena (2009) (see Table 2).

As previously stated, only marine silty-clayey rock types of the Plio-Pleistocene "Argille Azzurre" Formation crop out in the mountain catchment of the T. Corlo. The T. Corlo and its unnamed left tributary, which flows along the Vigne valley (meaning valley of the vineyards) (Fig. 4), are the main watercourses of the area. For simplicity's sake, the name of "Rio delle Vigne" was given to this small stream.

The T. Corlo and its tributary Rio delle Vigne are very small watercourses, with an intermittent regime, and in the summer they are practically devoid of water. In particular, in several stretches of its course the T. Corlo was artificially covered and therefore flows underground (Fig. 5).

Nine small to medium-sized artificial ponds make up other hydrographic elements. The biggest water bodies are located in the T. Corlo mid-valley; they are four ponds, some $100 \mathrm{~m}$ long and $10 \mathrm{~m}$ wide (Fig. 6) excavated around 2010; they appear in the AGEA 2011 ortho-photos but not in the 2008 ones. They resulted from abandoned quarries within the framework of the Riola Valley S.A. Project for the landscape and environmental reclamation of the $T$. Riola valley (ASQ-Consultingroup, 2008). Since these water bodies were not mapped on the CTR maps (Regional Technical Maps of Emilia-Romagna Region), the Geomorphological Map (Plate 1) also provides an updating of the previous map.

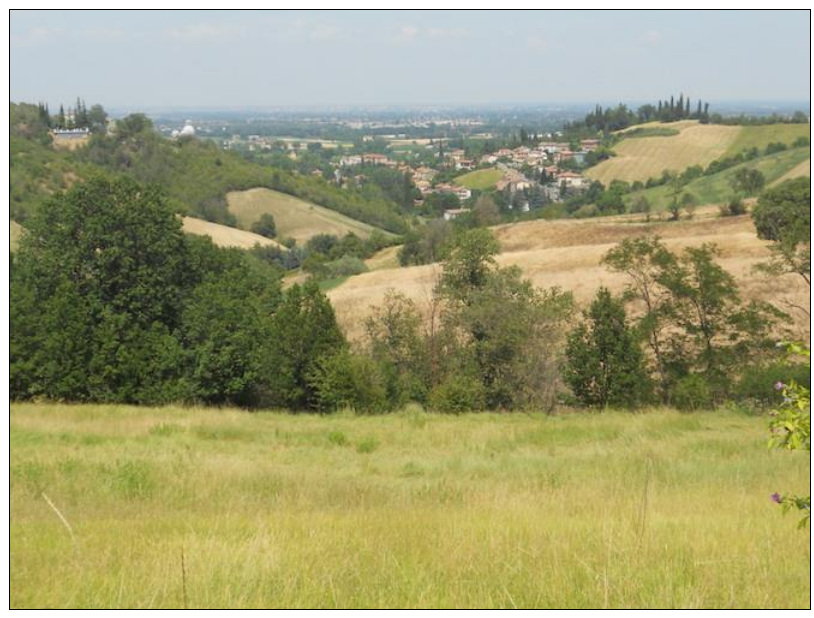

Figure 4 Rio delle Vigne valley. In the background the Modena alluvial plain.

Other anthropogenic hydrographic landforms are the emergence and submersion points of the $T$. Corlo (Fig. 5).

In any case, the most evident and heavily impacting anthropogenic landforms are all related to quarrying activities, which dominate the middle $\mathrm{T}$. Corlo valley (Plate 1), whereas the adjacent Vigne valley was spared. These man-made landforms (e.g. excavation, transport or deposit areas) have been classified as "abandoned" and "reclaimed" quarrying areas and edges of anthropogenic scarps. They still show their artificial origin.

Thanks to the presence of a clay formation, very suitable for ceramic tile production, and considering the proximity to the plain where industrial plants are located, quarrying activities were carried out in the T. Riola valley since the early 1900 s (cf. Ronconi 2000; ASQ-Consultingroup, 2008; Castaldini et al. 2012a, 2012c).

The reclaimed clay pits are mainly found on the valley floor, where the structures making up the Riola Valley Horse Riding Centre are located (Fig. 7). 
The abandoned clay pits are found on both right and left slopes, sometimes reaching the crests.

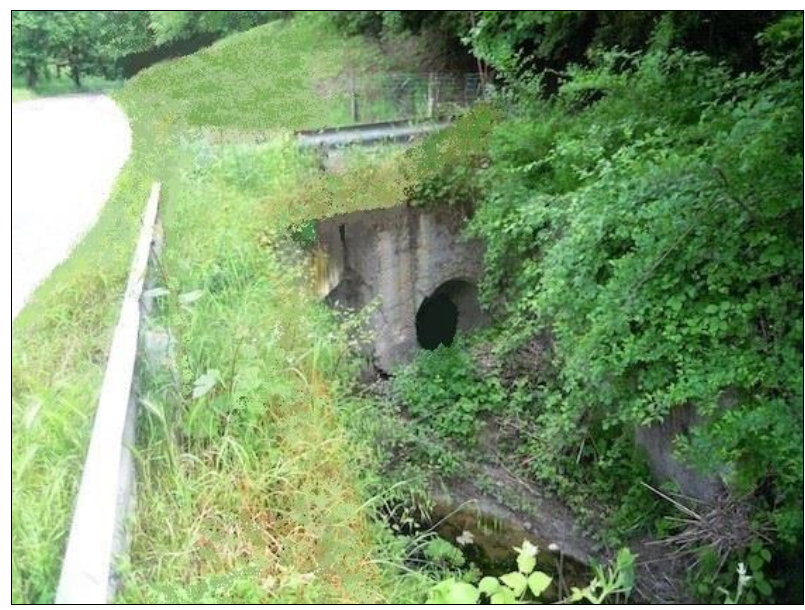

Figure 5 Submersion point of T. Corlo south of the village of Fiorano Modenese.

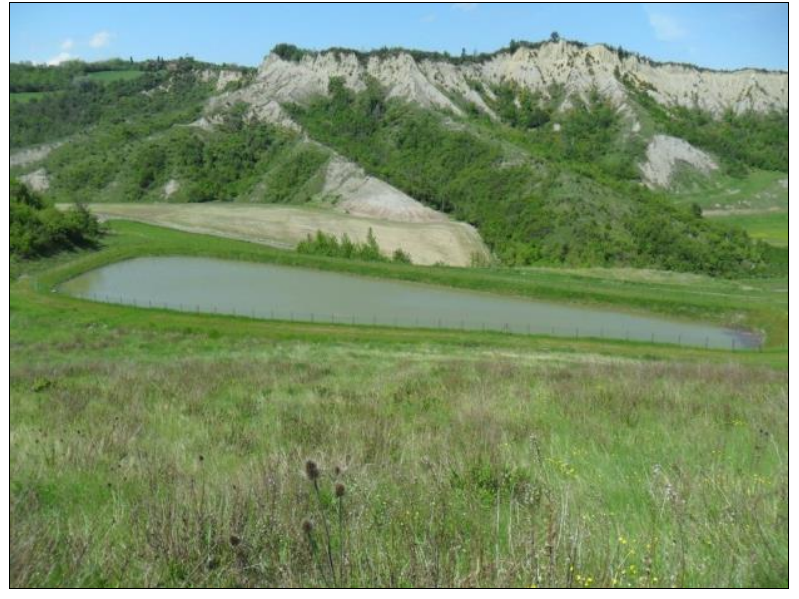

Figure 6 Artificial pond on the right hand-side of the T. Corlo mid-valley, which was produced from an abandoned clay pit. In the background, the badlands.

Artificial scarps are found nearly everywhere within the various quarrying areas, both abandoned and reclaimed. When these scarps still show a typical aspect related to quarrying activities they have been represented as anthropogenic landforms. On the other hand, when rill-wash or gravityinduced processes have considerably modified their appearance they have been represented as modelled by other morphogenetic agents.

Landforms and deposits due to superficial running waters are rather widespread in the T. Corlo catchment. They are: badlands, edges of scarps remodelled by water, concentrated runoff gullies, fluvial, colluvial and lacustrine deposits.

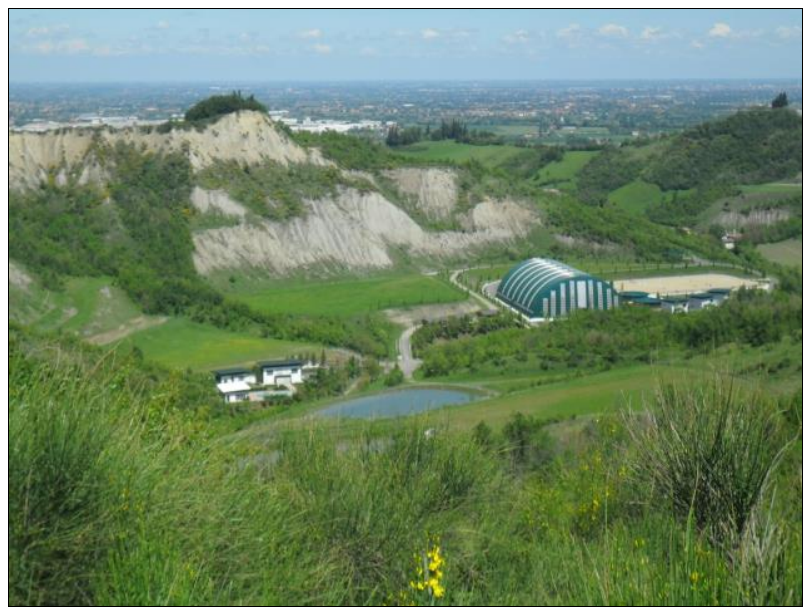

Figure 7 Panoramic view of Mt. Ave southern slope, which was heavily affected by quarrying. The clay pit area was reclaimed and the structures of the Riola Valley Horse Riding Circle were built on it. Notice the remodelling of the pit scarp by runoff waters. In the background the Modena alluvial plain.

In particular, typical examples of badlands can be observed in the T. Corlo upper and mid-valley. They are one of the most spectacular erosion landforms which affect the clayey soils of the Apennine northern margin. They are characterised by a high-density hydrographic network in which the single stream channels are separated by thin, blade-like crests. Runoff waters tend to have a thinning effect on the crests, also with the fundamental contribution of earth flows and earth slides, which have their crowns in the upper parts of the slopes. At present badland evolution affects many areas, owing also to the landslides which cause a rapid retrogression of the badlands' heads. Consequently, landslides from the crests that separate badlands located on contiguous slopes fill up the runoff channels with their deposits (Fig. 8). Generally speaking, the situation represented in the Geomorphological Map is merely indicative since it is practically impossible to map in detail all the landslide deposits which fill up the badlands' stream channels. 


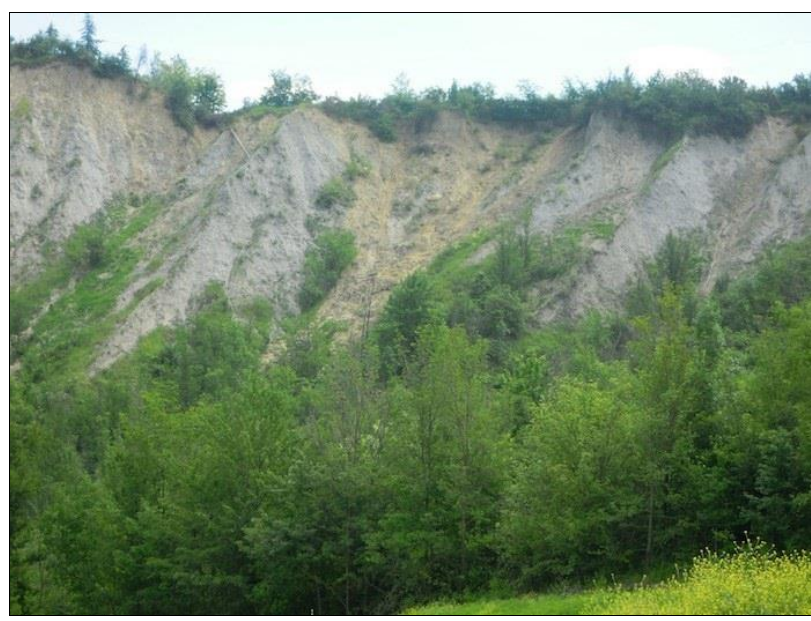

Figure 8 Example of badlands' head retrogression owing to slope movements. The ochre-coloured sandy tongues correspond to landslide deposits.

In this map the badlands have been distinguished as active or dormant, according to the activity of rill-wash erosion or landslide processes. Active badlands cover a much larger area than inactive badlands. The edges of active badlands, represented on the basis of the most recent remote sensing imagery, are in several points farther back than the edges shown in the CTR map. This fact bears witness to the intense activity of morphogenetic processes occurring in the past decades.

Among the landforms created by surface running waters, there are numerous runoff gullies cut along the main stream channels. Deposits of the main watercourses (with texture ranging from sand to clay) have been distinguished (where thicker than $1 \mathrm{~m}$ ) from colluvial deposits resulting from rill-wash down slopes (with texture from silt to clay), and from lacustrine deposits (clay).The alluvial deposits of the main watercourses have been mapped as dormant from the Rio Corlo - Rio delle Vigne confluence as far as the valley's mouth.

Colluvial deposits have limited extent and are widespread only in the lower portions of some slopes. In particular, at the foot of anthropogenic scarps, NW of the Riola Valley Horse Riding Centre, there are accumulations in progress of both colluvial and small earth flow deposits.

Finally, in the upper T. Corlo valley, there are lacustrine deposits related to old artificial water basins. These impoundments were built when quarrying activity was at its peak, in order to mitigate the effects of running water and safeguard service roads leading to the clay pits. In particular, in the valley SW of Corlo, lacustrine deposits are found on five levelled-out altitudes, between $175 \mathrm{~m}$ and $210 \mathrm{~m}$ circa. They have created a particular step-like longitudinal profile.

Gravity-induced slope landforms and deposits are common in both the T. Corlo valley and the Rio delle Vigne valley and are in great part due to earth flows, earth slides and soil slips (cf. Cruden \& Varnes, 1996), which are the typical landslides affecting silty-clayey rock types (Fig. 9).

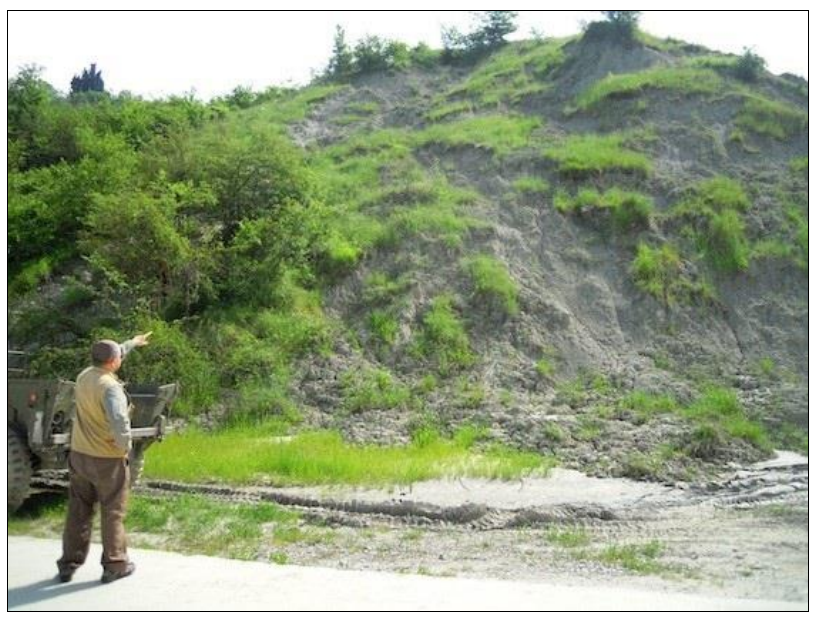

Figure 9 Active soil slip in the lower stretch of the T. Corlo valley.

The Geomorphological Map attached to this paper reports many more landslides than those shown on previous geological maps (cf. Gasperi et al., 1989, 2005; Regione Emilia-Romagna, 2017). In particular, many landslides have been identified in badland areas in the catchment's southern portion. They are active earth flows and earth slides, which have caused the retrocession of badlands' scarps and deposit their materials in the small valleys. In the northern portion of the study area, there are various active and dormant landslides, which affect the slopes of the lower T. Corlo valley and, in particular, the Rio delle Vigne valley. Several of these landslides were triggered or reactivated in late March-early April 2013 because of heavy precipitation occurring in the winter months. Their chronology was determined on the basis of field 
surveys carried out in different periods of the year and on local accounts.

The Geomorphological Map also shows the areas affected by solifluction, since this superficial morphogenetic process is considered to be among the causes of potentially unstable areas. Solifluction is typical of the finest soils and in the study area is found on several slopes where vegetation is absent. This research showed that in very recent years there has been an increase of morphogenetic processes, which have remodelled the badlands and caused previously undetected slope movements.

\section{Updated Hydrological Hazard Map}

As previously stated, in their territorial-planning phase, Municipalities and local boards can adopt without any change all data contained in the PTCP Hydrological Hazard Maps (Provincia di Modena, 2009) for assessing the geological instability situation of their territory. Nevertheless, they can also improve them through detailed investigations since Hydrological Hazard Maps represent a constantly evolving territory and consequently require constant updating.

The presence in the study area of mainly clayey rock types, which are easily erodible with a high capacity of absorption of precipitation and running water, makes the entire area particularly susceptible to instability, as shown by the numerous slope movements identified and mapped in the Geomorphological Map (Plate 1).

Notwithstanding this, the instability situation in the T. Corlo mountain catchment represented in the PTCP Hydrological Hazard Maps of Provincia di Modena (2009) is certainly underestimated (Fig. 10).

Therefore, since this study was financed by the Municipality of Fiorano Modenese, the updating of the PTCP Hydrological Hazard Map of the study area was implemented based on data collected and detailed field investigations carried out in the previous research steps (Fig. 11).

The updating of the PTCP Hydrological Hazard Maps implemented in this study (Fig. 11) shows a considerably different situation than the one shown by Provincia di Modena (2009) (Fig. 10). The great differences between the two maps, as pinpointed by
Castaldini et al. (2012b) in other areas of the Modena Apennines, are ascribable to the following causes:

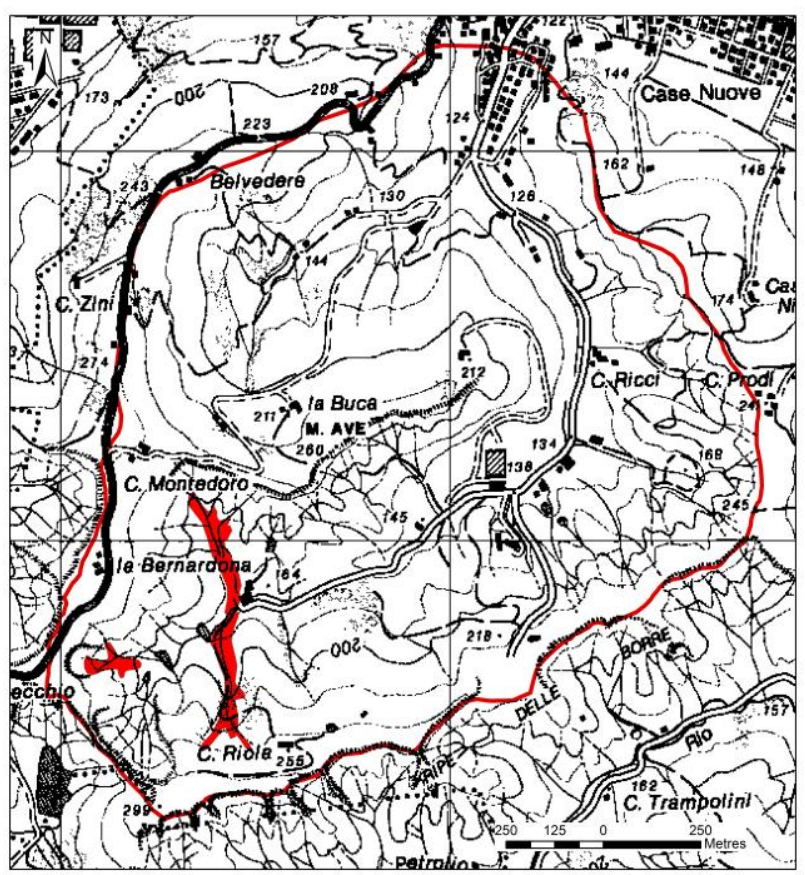

Figure 10 PTCP Hydrological Hazard Map (Provincia di Modena, 2009) of the T. Corlo mountain catchment. For the legend, see Table 2.

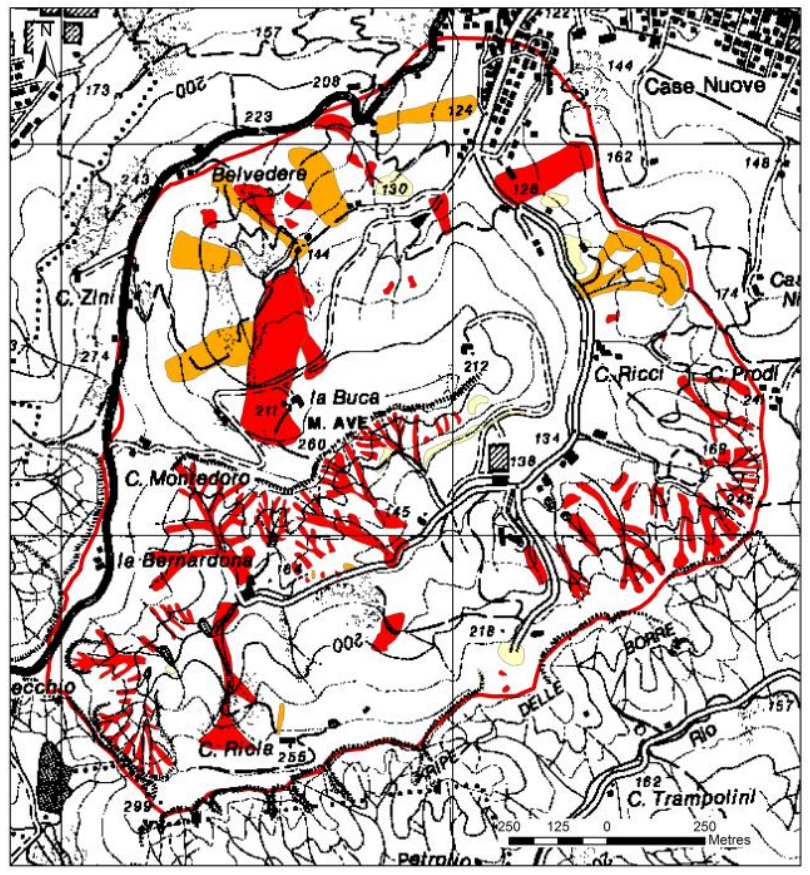

Figure 11 Our updated version (2017) of the PTCP Hydrological Hazard Map of the T. Corlo mountain catchment. For the legend, see Table 2. 
a) The PTCP Hydrological Hazard Maps are derived from the instability inventory of the EmiliaRomagna Region, which are in turn derived from the Regional Geological Cartography. In the latter, the morphogenetic processes and deposits have been given a secondary importance compared with lithology and tectonic-structural elements.

b) The updating of the instability inventory of the Emilia-Romagna Region has been carried out by means of 'occasional and patchy' studies, while the slope instability phenomena regularly occurring during the rainy seasons show that the Apennine territory is characterized by intense and active geomorphological dynamics. Therefore, thorough and periodic investigations should be necessary in order to update the slope instability situation.

Another determinative factor concerns the detail of investigations. Our Hydrological Hazard Map is derived from an updated Geomorphological Map (Plate 1) surveyed in detail, in which geomorphic processes and superficial deposits were given their proper importance.

Since several landslides were activated in the March-April 2013 period, because of a long rainy period, they could not be represented in the 2009 Hydrological Hazard Map. In fact, the 2009 PTCP Hydrological Hazard Map shows only some of the active landslides in the T. Corlo upper valley (Fig. 10). Instead, our Hydrological Hazard Map (Fig. 11) shows landslides occurring both in the T. Corlo valley and in the Rio delle Vigne valley. It shows that the areas affected by active landslides are much more widespread than the areas affected by dormant landslides. The landslides of Rio delle Vigne valley (both active and dormant) affect a wider surface than the landslides of the T. Corlo valley (Fig. 12). The causes of this can be ascribed to two factors: i) The intense remodelling of the $T$. Corlo valley due to quarrying activities (which will be discussed in the next chapter); therefore, the slopes could not have evolved according to natural patterns. ii) The presence of badlands in the T. Corlo valley alone; their evolution has taken place owing to both running waters and landslides, which cause a rapid retrogression of their heads and fill up the stream channels with long and narrow clay deposits.

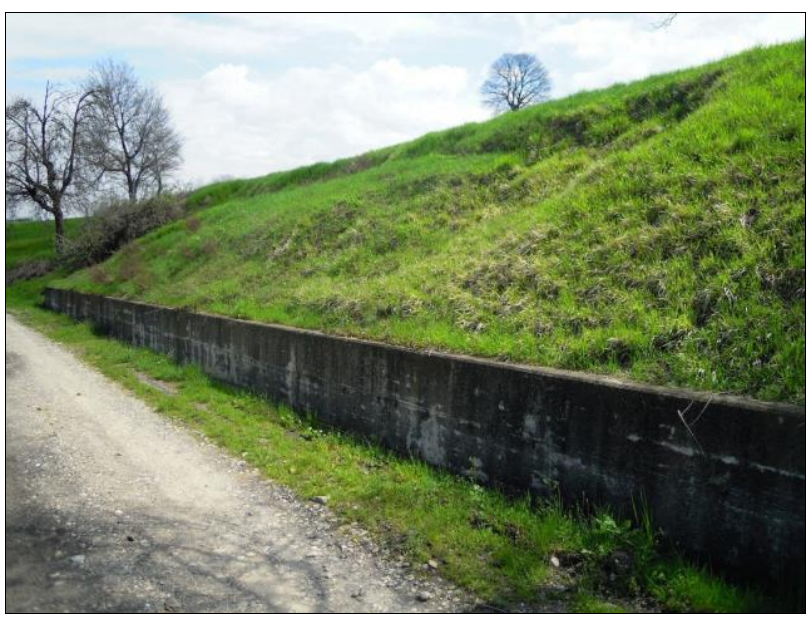

Figure 12 Upper Rio delle Vigne valley: eastern branch of the landslide which affected the road.

As for hydrological hazard, it can be observed that in the lowermost stretch of the T. Corlo valley, an area affected by an active landslide was mapped on the right side of the valley. In the past, this slope movement caused sliding of the stream's right bank. In the upper part of the valley two active landslides have been mapped which threaten some abandoned buildings. They originated on opposite slopes and have been classified as earth flows. In any case, the numerous active landslides occurring within the badlands' stream channels do not cause particular problems.

In the Rio delle Vigne valley some houses are located at the foot of dormant landslides, which so far have not caused instability problems. The large active landslide in the valley's upper part, which according to local inhabitants is periodically reactivated following intense precipitation, affects only superficial deposits and a stretch of the road (Fig. 12).

In the Hydrological Hazard Map implemented in this research, some "potentially unstable areas" have been represented by applying the legend of Table 2 . Similarly, also some areas affected by solifluction and active colluvial deposits have been represented, although they are not particularly significant from the hydrological hazard point of view.

\section{Geomorphological evolution}

The study of the geomorphological evolution of the landscape of the T. Corlo mountain catchment, 
which is characterised by uniform geo-lithological and climatic features all over its area, was based on numerous field surveys, the examination of topographic maps and multiscale and multitemporal remote sensing images, which are listed in Table 2.

Significant morphogenetic processes have not been identified in the Rio delle Vigne valley. Only small soil slips occurring on both sides of the valley's lower stretch can be reported. As previously stated, they were triggered following a high precipitation period in April-May 2013. These smallsized neoformation instability phenomena confirm that precipitation is one of the main triggering causes of landslides in the Northern Apennines (cf. Bertolini et al., 2001; Tellini, 2013).

On the contrary, in the T. Corlo valley the main morphogenetic agent was mankind, who exerted intense quarrying activities, thus causing considerable and irreversible landscape changes. The latter have been only partially mitigated thanks to the reclamation measures which have been implemented in the past ten years.

Clay excavation began in the T. Corlo valley in an improvised, makeshift way in the 1930s (ASQConsultinGroup, 2008). Anyhow, in the 1950s, the landscape of the T. Corlo valley still looked quite "natural", showing just three small clay pits in the middle sector. Quarrying was concentrated in the slope's lower portion on the left hydrographic side of the T. Corlo. In the 1970s, clay excavation activity was much more extensive, affecting also the right hydrographic side of the valley as well as upstream and downstream areas. Various artificial ponds and large levelled-out areas were present. These had been constructed in order to mitigate rill-wash erosion and safeguard dirt service roads leading to the clay pits. In addition, the lowest part of the valley had been developed, following the intense expansion of the village of Fiorano Modenese. In the 1990s, the clay exploitation areas on the left slope were abandoned whereas on the right slope clay exploitation activities were further expanded uphill with new excavation fronts, which in one place removed a stretch of the watershed with the conterminous T. Chianca valley. Quarrying activities for the ceramic tile industry ceased completely in
2008 (ASQ-ConsultinGroup, 2008). To date, manmade changes are clearly visible all over the T. Corlo valley, which appears to be characterised by levelled-out surfaces and slopes with artificial morphological profiles typical of excavation areas. Nevertheless, at present the remodelling of excavation fronts resulting from concentrated rill wash processes can be observed in various points. In some cases, the action of water running freely down slopes previously affected by artificial shaping tends to give them a more natural aspect. Sediments have filled some of the artificial ponds. Furthermore, in the upper portion of the slopes natural badlands can still be observed. In these areas rill wash water tends to narrow the interfluves, owing also to the fundamental contribution of superficial earth slides and earth flows. Present-day evolution of badlands takes place in many areas also because of small slope movements, which cause the rapid retrogression of the badlands' heads and the deposition of clay sediments along the stream channels.

\section{Final remarks}

A detailed study was carried out on the geomorphological evolution and the instability processes affecting the $\mathrm{T}$. Corlo mountain catchment, which comprises the main T. Corlo valley and the tributary Rio delle Vigne valley.

The cartographic documents produced in this research - a Geomorphological Map (Plate 1) and a Hydrological Hazard Map - were elaborated by means of a GIS software programme, using as a base map the most recent topographic map, updated to the mid-2000s, of Carta Tecnica Regionale (CTR) of Emilia-Romagna Region.

The T. Corlo mountain catchment is an exemplary study case in which two conterminous small valleys with the same geo-lithological and climatic characteristics have undergone quite different morphological evolutions.

The Rio delle Vigne valley has been affected only by natural gravity-induced processes, which have produced some twelve landslides, half of which have been classified as active (according to the definition shown in Table 2), although they have not 
had any particular influence on the valley's morphology.

In the T. Corlo valley, on the other hand, excavation activities have drastically changed the landscape characteristics. In particular, clay excavation began in an improvised, makeshift way in the 1930s. By the 1960s, excavation was carried out in a more organized, industrial way. Soon after the cessation of quarrying activities in 2008, the whole area previously affected by the presence of several clay pits was the object of a project of landscape and environmental reclamation and upgrading, which included the implementation of a horse riding centre and some small ponds for recreational purposes.

Finally, a detailed assessment is made of the fundamental role played by excavation activity as a morphogenetic agent of the T. Corlo valley as well as its impact on the natural evolution of the landscape. This study case confirms once more that anthropogenic activity is a very rapid morphogenetic agent with a high impact on the landscape. Not even a project of landscape and environmental reclamation will be able to put right the man-made changes completely and reconstruct the original landscape of the T. Corlo valley.

As for the instability of the whole mountain catchment of T. Corlo, the landslides identified in this study and shown on the Geomorphological Map (Plate 1) are much more numerous than those reported in the more or less recent geological maps (e.g., Gasperi et al., 1989, 2005; Regione EmiliaRomagna, 2017).

Consequently, the areas affected by active landslides and those affected by dormant landslides shown in our updated version of the PTCP Hydrological Hazard Map (Fig. 11) are much more numerous than those mapped in the PTCP Hydrological Hazard Map of Provincia di Modena (2009) (Fig. 10).

Since the PTCP Hazard Maps are the only reference documents for municipal urban planning with respect to hydrological safety regulations, they should be used just as "base documents", as pointed out by Castaldini et al. (2012b). Indeed, they require more in-depth investigations at a local scale to be fully reliable. This can be accomplished only by means of accurate geomorphological mapping, at least for the areas that are going to be developed. As asserted also by Farabollini \& Pambianchi (2011), accurate geomorphological mapping is of paramount importance for territorial planning. Updated geomorphological maps should represent not only the evolution of artificial features but also the elements of the physical landscape (such as watercourses, scarps etc.) which might have changed since the official topographic base maps were elaborated.

In addition, professional geologists could carry out detailed geomorphological mapping in the executive phases of a reclamation project in accordance with standard procedures set up in collaboration with the public authorities, especially when private purchasers play a major role. This could be a feasible solution, also in terms of economic balance, in order to achieve progressively more accurate hydrological hazard mapping, without putting heavy economic burdens on public authorities.

\section{References}

Asq-Consultingroup 2008., Riola Valley S.A. Progetto per la riqualificazione paesaggistica e ambientale. Comune di Fiorano Modenese, Provincia di Modena, Vols. 1 and 2, 166 pp.

Bertolini G, Pellegrini M, Tosatti G. (eds.) 2001. Le frane della Regione Emilia-Romagna, oggetto di interventi di Protezione Civile nel periodo 1994-1999. Quaderni di Geologia Applicata, 8(1-2), 428 pp., Pitagora, Bologna.

Bruschi VM, Coratza P, Piacentini D, Soldati M. 2012. Geomorphological features of the Rio della Rocca valley (Northern Apennines, Italy). Journal of Maps, DOI:10.1080/17445647.2012.744705.

Castaldini D, Coratza P, Liberatoscioli E, Tosatti G. 2012a. Soil excavation as the main morphogenetic agent in the Torrent Corlo Valley (Northern Apennines, Italy). In: Proceedings 7th EUREGEO Sustainable GeoManagement, Bologna, 12-15 June 2012, vol. 1, pp. 144-145, Bologna. 


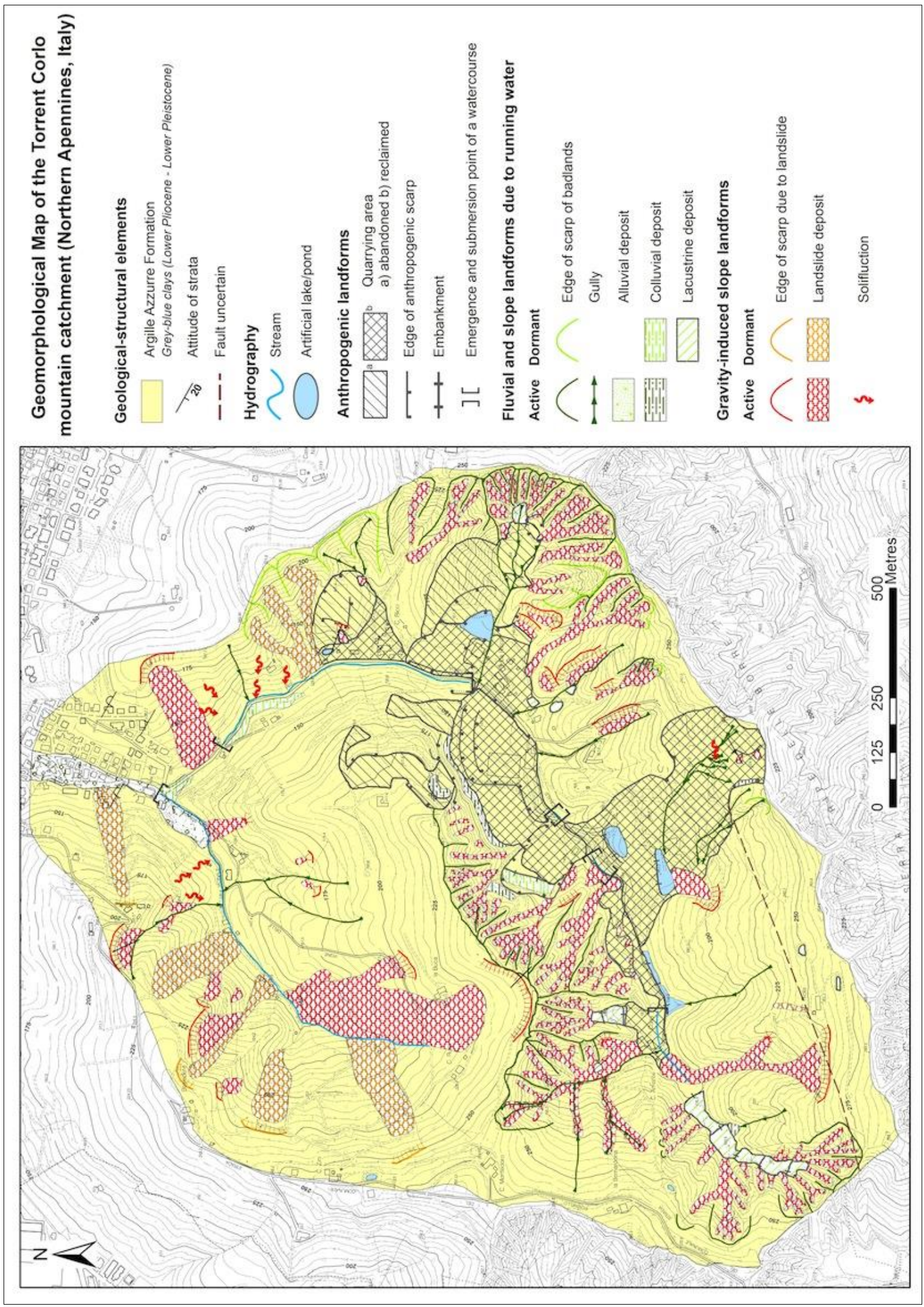

Plate 1 Geomorphological map. 
Castaldini D, Ghinoi A, Maccaferri A. 2012b. Considerations on geomorphological maps for territorial planning in the Modena Apennines (Northern Italy). Nat. Hazards Earth Syst. Sc., 12, pp. 421-430.

Castaldini D, Tosatti G, Coratza P, Cameroni A. 2012c. Evoluzione morfologica delle aree estrattive nel territorio di Fiorano Modenese (MO). Atti Soc. Nat. Mat. di Modena, 143, pp. 71-89.

Castaldini D, Coratza P, De Nardo MT 2017. Geologia e Geomorfologia delle Salse di Nirano. In: D. Castaldini, M. Conventi, P. Coratza, G. Tosatti (eds.) "Studi interdisciplinari in Scienze della Terra per la fruizione in sicurezza della Riserva Naturale delle Salse di Nirano", Suppl. Atti Soc. Nat. Mat. di Modena, 148, pp. 23-58.

Cruden DM, Varnes DJ 1996. Landslide Types and Processes. In A.K. Turner \& R.L. Schuster (eds.) "Landslides Investigation and Mitigation", Special Report 247, 3, pp. 36-75, Transportation Research Board, National Academy Press, Washington, D.C.

Dramis F, Bisci C. 1998. Cartografia geomorfologica. Manuale di introduzione al rilevamento ed alla rappresentazione degli aspetti fisici del territorio. Pitagora, Bologna, 232 pp.

Farabollini P, Pambianchi G 2011. La geomorfologia ed il rilevamento geomorfologico applicato alla pianificazione territoriale: uno strumento di previsione, prevenzione e controllo del paesaggio naturale ed antropico. Geologia Tecnica \& Ambientale, 1/11, pp. 32-41.

Fazzini M. 2007. Caratterizzazione climatica della zona di Nirano. In: D. Castaldini, S. Conti, M. Conventi, D. Dallai, C. Del Prete, M. Fazzini, D. Fontana, C. Gorgoni, A. Ghinoi, A. Russo, L. Sala, P. Serventi, D. Verri \& M. Barbieri "Le Salse di Nirano", CD-ROM, Enciclopedia Multimediale, Comune di Fiorano Modenese.
Fell R, Corominas J, Bonnard C, Cascini L, Leroi E, Savage WZ 2008. Guidelines for landslide susceptibility, hazard and risk zoning for land-use planning. Engineering Geology, 102(3-4), pp. 99-111.

Gasperi G, Bettelli G, Panini F, Pizziolo M, Bonazzi U, Fioroni C, Fregni P, Vaiani SC 2005. Note Illustrative e Carta Geologia d'Italia alla scala 1:50.000, Foglio n. 219 Sassuolo. SELCA, Firenze.

Generali M, Pizziolo M 2012. The susceptibility map for shallow landslides initiation in the Emilia-Romagna Region (Italy). In: C. Margottini, P. Canuti, K. Sassa (eds.) "Landslide Science and Practice", Springer, Heidelberg.

Gruppo di lavoro per la cartografia geomorfologica (1994), Carta geomorfologica d'Italia - 1:50.000, Guida al rilevamento. Serv. Geol. Naz. Quad., III, 4, Roma, 47 pp.

Panizza M, Corsini A, Ghinoi A, Marchetti M, Pasuto A, Soldati M. 2011. Explanatory notes of the Geomorhological Map of the Alta Badia valley (Dolomites, Italy). Geog. Fis. Dinam. Quat., 34, pp. 105-126.

Provincia di Modena 2009. PTCP. Piano Territoriale di Coordinamento Provinciale. Variante di adeguamento in materia di dissesto idrogeologico ai Piani di Bacino dei fiumi Po e Reno. Area Programmazione e Pianificazione Territoriale.

Regione Emilia-Romagna 2017. Cartografia geologica online in scala 1:10.000 della Regione Emilia-Romagna. Website: http://www.regione.emiliaromagna.it/wcm/geologia/canali/cartografia/sito.

Ronconi L. 2000. Aggiornamento del catasto delle cave storiche della Provincia di Modena. Provincia di Modena.

Tellini C. 2013. Pericolosità e suscettibilità da frana in Emilia-Romagna. Il Geologo dell'Emilia-Romagna, 47, anno XIV, pp. 7-13, Bologna. 